The Journal of Animal \& Plant Sciences, 30(2): 2020, Page: 319-324

ISSN: 1018-7081

\title{
POTENTIAL USE OF CARIUM CARVI AND CURCUMA LONGA FOR THE REMEDY OF SKIN AND SOFT TISSUES PATHOGENS
}

\author{
H. Khan ${ }^{1}$, J. Khan ${ }^{1,2}$, S. Gul ${ }^{3}$, M. I. Khan ${ }^{3}$, H. Khan ${ }^{4}$ and M. A. Khan ${ }^{* 3}$ \\ ${ }^{1}$ Department of Microbiology, Kohat University of Science \& Technology, Kohat, Pakistan \\ ${ }^{2}$ University of Swat, Pakistan; ${ }^{3}$ Department of Chemistry, Kohat University of Science \& Technology, Kohat, Pakistan; \\ ${ }^{4}$ Department of Pharmacy, Abdul Wali Khan University Mardan, Pakistan \\ *Corresponding Author's E-mail: drmalikhan@yahoo.com
}

\begin{abstract}
The Pathogens responsible for the skin and soft tissue infections are often prone to develop resistance to antibiotics. A good alternative to this resistance is the use of folk medicine. For this purpose two plants Carium carvi and Curcuma longa, used in folk medicine were tested against the selected pathogens, Staphylococcus aureus, Staphylococcus epidermidis, Pseudomonas aerugenosa and Streptococcus pyogenes. The pathogenswere collected from the patients having skin and soft tissues infections. The isolated pathogens were identified through microscopic studies followed by biological tests using Sigma Aldrich KGaA Merck kit protocol. These plant materials were extracted with $\mathrm{MeOH}$ and then portioned among different solvents, based on their polarity. These extracts were then applied against the selected pathogens, using well diffusion assay method and the minimum inhibitory concentration (MIC). The results showed marked antibacterial activity in the chloroform and ethyl acetate extract (18 $\mathrm{mm}$ zone of inhibition each) of Carium carvi seeds while the chloroform extract of Curcuma longa showed (21 mm zone of inhibition) promising results. Sensitivity of various extracts of the plant in a concentration dependent manner with significant MIC values was determined. Our findings showed that the extracts of $C$. longa and $C$. carvi seeds possess strong antibacterial effects against clinically isolated skin and soft tissue pathogens.
\end{abstract}

Keywords: Carium carvi, Curcuma longa, Skin diseases, Pathogens, Antibacterial activity.

https://doi.org/10.36899/JAPS.2020.2.0049

Published online March 02, 2020

\section{INTRODUCTION}

Skin diseases are producing a high health concern both in developed and developing countries, in all ages from children to the old people and are one of the five causes for medical deliberation. A basic problem associated with these skin disease causing pathogens is the creation of resistance. The antibiotic resistance is on the rise in the whole world at an alarming rate which is threatening the human ability to treat even some common diseases successfully. Only in the United states of America, the methicillin resistant Staphylococcus aurens (MRSA) has affected nearly 126,000 people and causes 1860 deaths every year. This number is more than the deaths caused by AIDS (Quave et al., 2012). As the skin disease are more in the poor population in the remote areas of Asia and Africa where the health care and the modern health facilities are in scarcity. Therefore these people are a lot dependent upon the natural remedies. In this situation the natural products are the best source of drugs and drug leads, and this is still true despite the enormous development in the synthetic drugs. The natural product poses unique structural and chemical diversity that is unparallel by the synthetic world. In this situation the folk resources of medicinal origin for control of antibiotic resistant pathogenic bacteria is increasing with every passing day due to the increasing side effects of the synthetic drug (Khan et al., 2015; Khan et al., 2016). Medicinalplants have been an effective source of widely acceptable and efficient medicines because of the popular assumption that the herbal medicines cause fewer or no side effect and are effective agents against a broad range of antibiotic resistant microorganisms (Bashir et al., 2014). C. carvi and Curcuma longa are the two plants used in northern areas of Pakistan for the cure of skin related diseases.

Carium carvi (Zankay) belongs to family Apiaceae is the oldest herbs, having a pleasant smell, found in Africa, Asia and Europe. Its fruits are used in medicine, fragrance and for cooking purposes. C. carvi consist of important nutrients such as vitamin A, B complex, vitamin $\mathrm{C}$ and $\mathrm{E}$. The desiccated fruits of $C$. carvi are used in medicine as a flatulence carminative, they are helpful against spasmodic, gastrointestinal complaint, irritable stomach, dyspepsia, lack of hunger in adult (Sibi et al., 2013). C. carvi oil has antimicrobial, antifungal, molluscidal, nematicidal, anti oxidant and anti carcinogenic (Satish et al., 2008; Jain et al., 2010; Abhilash et al., 2011). It's extract posses in vitro antibacterial activity against $H$. pylori, the alcoholic extract of C. carvi inhibit the growth of Klebsiella pneumonia. Antifungal activity of C. carvi is recorded 
against animal, food and soil fungi such as dermatophyte, mycotoxin and yeast.(Razzaghi-Abyaneh et al., 2009). The seed of $C$. carvi is used in the healing of bronchitis and is an element of cough remedy, especially valuable for children and mothers for enhancement of breast milk (Chevallier, 2001). It is used to improve liver functions and as a remedy for headache, when mixed with castor oil is used for scabies (Sivarajan and Balachandran, 1994). The C. carvi essential oils have also been used as an anti ulcerogenic, antitumor, antiproliferative and antihyperglycemic agent (Thippeswamy et al., 2013).

Curcuma longa (Family: Zingiberaceac), is an evergreen herbaceous plant grown widely in the subcontinent, Africa, China, India and some countries of South America. The use of Curcuma longa has raised due to its coloring property and pleasant odor in food (Amin, 1991). The phenolic compounds, curcuminoid dyes and essential oils are responsible for the antioxidant activity of turmeric plant (Nafissi, 1990). Phenolic compounds of Curcuma longa exhibits the potential to destroy cell walls of target bacteria and enter into the microbial cell and affect the metabolism of the cell (Končić et al., 2010). The anti-protozoal, anti-venom, anti-HIV, anti-tumor activities have also been reported of the Curcuma longa (Shamsa et al., 1999; Turkmen et al., 2006; Arayne et al., 2007; Farhoosh et al., 2007). Curcuma longa consists of curcumin used for antimicrobial skin gels and for wound covering properties (Zhou et al., 2009). Curcumin also possesses inhibitory activity against methicillin-resistant Staph. aureus (Kong et al., 2009). Curcumin activates Inosine monophosphate dehydrogenase (IMPDH) enzyme which can inhibit guanine nucleotide synthesis and is suggested as a antiviral and anticancer drug (Kumar et al., 2010). Curcumin inhibit viral long terminal repeat (LTR) and a consequent can inhibit type 1 human immunodeficiency virus (HIV-1) virus transcription. Methanolic extract of Curcuma longa show antifungal activity against Candida albicans and Cryptococcus neoformans (Raghavendra et al., 2006). As an anti-inflammatory substance having a liver protective effect has also been reported. The anti-allergy, insectrepellant and anti-ulcer activities are additionally reported (Babu et al., 2007).

In the present study different solvent extracts of C. carvi and C. longa, the plants which are used indigenously for skin cure, against clinically isolated skin pathogens including P.aerugenosa, S.aureus, S.epidermidis and S.pyogenes were investigated.

\section{Experimental}

Study Area and Sampling: The sample of plants $C$. carvi and $C$. longa were collected from District Khar. The plant material was identified by plant taxonomist from the Department of Botany, and was given the voucher specimen no KUST 424 deposited in the herbarium of Kohat University of Science and Technology (KUST).

ExtractionandFractionation: Chopped the one kilogram dried plant samples into pieces and then grinded into powder. The powder materials of the plants were dipped in methyl alcohol with occasional shaking for 12 days at room temperature in the laboratory of the Department of Chemistry, Kohat University of Science \& Technology (KUST). The solvent was filtered after every 4 days and the filtrate was concentrated using vacuum rotary evaporator at $42{ }^{0} \mathrm{C}$. The plant powder was again dipped in methanol and repeated the above mentioned process three times. At the end combined all the filtrates and concentrated till dryness and then dissolved in distilled water. This water solution was then extracted with nhexane, chloroform and ethyl acetate in succession to get the extracts of n-hexane, chloroform and ethyl acetate.

Collection and Identification of Bacteria: Bacterial samples were collected from Hayatabad Medical Complex (HMC) and North West General Hospital (NWGH) Peshawar, Khyber Pakhtunkhwa in Nutrient broth tubes. The patients consent was sorted for the collection of samples and further work. These cultured bacteria namely $P$. aerugenosa, $S$. aureus, $S$. epidermidis and $S$. pyogenes were stained with Gram's stain and subjected to microscopic observation for the identification of their cell morphology. The results based on microscopic observation were further confirmed using biochemical tests. For this purpose the Catalase, Coagulase, DNase and Oxidase tests were performed as per Sigma Aldrich KGaA Merck kit protocol 2010. The results are given in Table 1.

Culture Meida: Mac Conkey and Blood agar was used to culture the bacteria. Both have different characteristics. Mac Conkey agar is a differential media for Gram Negative Bacteria. Blood agar acts as an enriched media facilitating the growth of Gram Positive Bacteria and differentiates Bacteria on the basis of heamolysis of blood.

Bacteria Culture: The bacteria strains were cultured on Nutrient agar and Muller Hinton agar (MHA) media. Nutrient agar media enhances the growth of bacteria while the MHA was used for susceptibility testing of the selected bacteria against the plant extracts and antibiotics. The bacteria culture was refreshed in nutrient broth for 24 $\mathrm{h}$ at $37^{\circ} \mathrm{C}$ before inoculation of bacteria (Ahmad and Aqil, 2007).

Bacterial Susceptibility Testing: Well diffusion assay and minimum inhibitory concentration (MIC) methods were used for the determination of antibacterial potential of different fractions of the plant extracts. For the assay four strains of skin bacterial pathogens namely, $P$. aerugenosa, $S$. auerus, $S$. epidermidis and $S$. pyogenes 
were used. The Mueller Hinton agar (Oxide, UK) media was prepared in a conical flask according to the manufacturer directions. After preparation of media in the flask, the media was poured in the plates. After the media was solidified in plates, inoculated fresh culture of the strain (adjusted to 0,5 McFarland turbidity) on each plate by means of spreader. Seven wells ( $6 \mathrm{~mm}$ diameter each) were made through cork borer in the plates and then added $100 \mu \mathrm{l}$ of the plant extract through micropipette. Used dimethylsulfoxide (DMSO) as negative control, while the Impenim (Standard antibiotic) as positive control. Labeled the plates and placed in incubator for 24 hrs at $37^{\circ} \mathrm{C}$ for aerobic incubation. Zone of inhibition was measured by a scale in millimeter (Coyle, 2005). The results of antibacterial activity of extracts of Carum carvi andCurcuma longa, against skin pathogens are shown in Table 2 and 3.

Minimum Inhibitory Concentrations (MICs): The plant extracts were checked for their qualitative antibacterial activity against the selected pathogens through MIC method. Took $10 \mathrm{ml}$ nutrient broth in a 15 $\mathrm{ml}$ sterilized, caped tube and then inoculated with $100 \mu \mathrm{l}$ of overnight bacterial broth cultures, matched to 0.5 McFarland standards (Kumar et al., 2010). ). The only nutrient broth was taken as negative control while the positive control was nutrient broth having bacterial culture. The tubes were then incubated at $37^{\circ} \mathrm{C}$ for $24 \mathrm{~h}$ and recorded the results (Coyle, 2005). The MIC values of various extracts of the plants are given in Table 4

Phytochemical Analysis: The active metabolites of the plants like glycosides, steroids, tannins, terpenoids, alkaloids, flavonoids amino acids saponin were determined qualitatively (Bladt, 2009). Crude extract of C. carvi consist of carbohydrate in high concentration, alkaloid, phenol, tannins and starch were in moderate concentration while glycoside, saponin, flavonoid and protein were not found while in $C$. longa the carbohydrate was in high concentration, the alkaloid, glycoside, tannins were in moderate concentration while, saponin, flavonoid, starch and phenol were not found as shown in Table 5.

Statistical Analysis All the experiments for determining the zone of inhibition were performed in triplicate, mean zone of inhibition and standard deviation were calculated. The results were expressed as mean \pm standard deviation. Statistical analysis was done by one way ANOVA. The statistical significant value was set at $\mathrm{p}<0.05$.

\section{RESULTS AND DISCUSSION}

The antibiotic resistance is on the rise in the whole world at an alarming rate which is threatening the human ability to treat even some common diseases successfully (Loke and Hanafi, 2019). In this situation the natural products are the best source of drugs and drug leads, and this still true despite the enormous development in the synthetic drugs. The natural product poses unique structural and chemical diversity that is unparallel by the synthetic world. In this situation the folk resources of medicinal origin for control of antibiotic resistant pathogenic bacteria is increasing with every passing day due to the increasing side effects of the synthetic drug (Ullah et al., 2013; Khan et al., 2015). Plants have been an effective source of natural and efficient medicines because it is assumed that plant based medicines cause fewer or no side effect and influence a broad range of antibiotic resistant microorganisms (Bashir et al., 2014). Two local medicinal plants Carum carvi andCurcuma longa were checked for the activities against skin and soft tissues pathogens. Methicillinresistant $S$. aureus (MRSA) is widely recognized as a nosocomial pathogen in health related zones. It is now emerging as a prominent cause of community acquired infections across the world and also reported in healthy individuals without risk factors (Iyer and Jones, 2004; Fleming et al., 2006). The results of our finding showed prominent susceptibility of various extracts of $C$. carvi seeds and C. longa against clinically isolated $S$. aureus. $S$. epidermidis has been recognized as an opportunistic human pathogen and a pre-dominant cause of nosocomial infections in recent years. Its pathogenicity is primarily attributed to the ability to form biofilms on indwelling medical devices. Staphylococcus epidermidis is protected in a biofilm, against attacks from the immune system and against antibiotic treatment, making $S$. epidermidis infections difficult to eradicate (Vuong and Otto, 2002). When we tested the extracts of C. carvi seed and C. longa against clinically isolated $S$. epidermidis, marked antibacterial effect was observed. It is, therefore, strongly recommended to lunch further detail studies to investigate its effect followed by bioactivity guided isolation of secondary metabolites for better understanding and clinical significance.

Emerging antibiotic resistance of $S$. pyogenes (erythromycin resistance) is alarming, because it is one of the common causes of a variety of skin and soft-tissue infections and because empirical choices of antimicrobials must include agents with activity against resistant strains (Stevens et al., 2014). Minor skin and soft-tissue infections may be empirically treated with commonly used antibiotics, but resistance cases will be difficult to treat. Based on the results of our study on the extracts of $C$. carvi seed and C. longa, it could be a useful natural alternative to current synthetic agents. $P$. aeruginosais an important causative agent of skin and soft tissues nosocomial infections, particularly in patients with compromised host defense mechanisms. It is the most common pathogen isolated from patients who have been hospitalized longer than one week. If not properly treated, such infections can be life-threatening. Multiple 
drug resistant has been frequently reported to $P$. aeruginosa infections in literature (Paterson, 2006). The extracts of $C$. carvi seed and $C$. longa showed promising result against clinically isolated $P$. aeruginosa. The study shows that mostly the chloroform and ethyl acetate extracts has shown good activity while in some cases the hexane extract has performed better, this indicate that the non polar or less polar compounds like terpenes, alkaloids and tannins might be the active ingredients of the plant extracts. As the extracts of $C$. carvi seed and $C$. longa showed promising result against these pathogens, thus the extracts of these plants could be a useful alternative to current available therapies.

Table 1. The biochemical tests for the identification of bacteria.

\begin{tabular}{cll}
\hline S.No & \multicolumn{1}{c}{ Bacteria } & \multicolumn{1}{c}{ Biochemical Tests } \\
\hline 1 & Staphylococcus aureus & Catalase +ve, Coagulase +ve, DNase test +ve, \\
2 & Staphylococcus epidermidis & Catalase $+\mathrm{ve}$, Coagulase -ve, Dnas test $-\mathrm{ve}$, Oxidase $-\mathrm{ve}$. \\
3 & Streptococcus pyogenes & Catalase $-\mathrm{ve}$, Coagulase $-\mathrm{ve}$, DNase $-\mathrm{ve}$, \\
4 & Pseudomonas aerugonosa & Oxidase $+\mathrm{ve}$, Catalase +ve. Coagulase $-\mathrm{ve}$. \\
\hline
\end{tabular}

Table 2. Antibacterial activity of extracts of Carium carvi seed against skin pathogens.

\begin{tabular}{llcccc}
\hline \multirow{2}{*}{ Extracts } & Concentration & \multicolumn{4}{c}{ Zone of inhibition (mm) } \\
\cline { 3 - 6 } & & Staphylococcu aureus & $\begin{array}{c}\text { Streptococcus } \\
\text { pyogenes }\end{array}$ & $\begin{array}{c}\text { Staphylococcus } \\
\text { epidermidis }\end{array}$ & $\begin{array}{c}\text { Pseudomonas } \\
\text { aerugenosa }\end{array}$ \\
\hline Positive control & & $33.33 \pm 1.6$ & $31.889 \pm 1.6$ & $27.778 \pm 1.1$ \\
Hexane & $12.5 \mathrm{mg} / \mathrm{ml}$ & $1.000 \pm 0.9$ & $1.667 \pm 1.2$ & $1.667 \pm 0.8$ & $2.333 \pm 1.5$ \\
& $25 \mathrm{mg} / \mathrm{ml}$ & $10.333 \pm 1.0$ & $11.667 \pm 0.5$ & $11.000 \pm 1.0$ & $12.333 \pm 0.1$ \\
& $50 \mathrm{mg} / \mathrm{ml}$ & $18.000 \pm 0.8$ & $16.667 \pm 1.2$ & $18.333 \pm 1.2$ & $15.333 \pm 1.5$ \\
Chloroform & $12.5 \mathrm{mg} / \mathrm{ml}$ & $3.000 \pm 0.8$ & $1.667 \pm 1.2$ & $1.667 \pm 1.2$ & $1.667 \pm 0.9$ \\
& $25 \mathrm{mg} / \mathrm{ml}$ & $11.333 \pm 1.2$ & $12.000 \pm 1.8$ & $9.000 \pm 1.2$ & $10.667 \pm 1.5$ \\
Ethyl acetate & $50 \mathrm{mg} / \mathrm{ml}$ & $15.667 \pm 1.5$ & $16.667 \pm 1.6$ & $18.000 \pm 1.5$ & $17.333 \pm 1.5$ \\
& $12.5 \mathrm{mg} / \mathrm{ml}$ & $1.667 \pm 0.9$ & $2.667 \pm 1.2$ & $2.000 \pm 1.2$ & $1.667 \pm 0.4$ \\
Aqueous & $25 \mathrm{mg} / \mathrm{ml}$ & $12.000 \pm 1.6$ & $14.000 \pm 1.8$ & $13.33 \pm 1.6$ & $12.333 \pm 1.8$ \\
& $50 \mathrm{mg} / \mathrm{ml}$ & $17.667 \pm 1.5$ & $18.333 \pm 1.8$ & $17.000 \pm 1.8$ & $14.667 \pm 1.2$ \\
DMSO & $12.5 \mathrm{mg} / \mathrm{ml}$ & $1.000 \pm 0.2$ & $1.667 \pm 0.5$ & $1.667 \pm 0.8$ & $1.667 \pm 0.5$ \\
& $25 \mathrm{mg} / \mathrm{ml}$ & $8.000 \pm 1.6$ & $6.333 \pm 1.2$ & $10.667 \pm 1.6$ & $10.000 \pm 1.2$ \\
& $50 \mathrm{mg} / \mathrm{ml}$ & $12.333 \pm 1.6$ & $16.333 \pm 1.2$ & $13.000 \pm 1.8$ & 0.000 \\
\hline
\end{tabular}

Values are mean \pm SEM of three independent experiments. . DMSO: Dimethyle Sulfoxide

Table 3. Antibacterial activity of extracts of Curcuma longa seed against skin pathogens.

\begin{tabular}{|c|c|c|c|c|c|}
\hline \multirow[b]{2}{*}{ Extracts } & \multirow[b]{2}{*}{ Concentration } & \multicolumn{4}{|c|}{ Zone of inhibition (mm) } \\
\hline & & Staphylococcu aureus & $\begin{array}{l}\text { Streptococcus } \\
\text { pyogenes }\end{array}$ & $\begin{array}{c}\text { Staphylococcus } \\
\text { epidermidis }\end{array}$ & $\begin{array}{c}\text { Pseudomonas } \\
\text { aerugenosa }\end{array}$ \\
\hline Positive control & & $27.444 \pm 1.7$ & $30.667 \pm 0.9$ & $29.889 \pm 2$ & $29.556 \pm 2$ \\
\hline \multirow[t]{3}{*}{ Hexane } & $12.5 \mathrm{mg} / \mathrm{ml}$ & $3.000 \pm 0.2$ & $1.667 \overline{+0} .2$ & $2.000+0.5$ & $0.667 \pm 0.5$ \\
\hline & $25 \mathrm{mg} / \mathrm{ml}$ & $12.333+1.6$ & $7.333 \pm 1.6$ & $11.000 \pm 1.2$ & $11.333+1.2$ \\
\hline & $50 \mathrm{mg} / \mathrm{ml}$ & $18.667 \pm 1.6$ & $15.33 \overline{3}+2$ & $17.66 \overline{7} \pm 2$ & $18.000 \pm 1.8$ \\
\hline \multirow[t]{3}{*}{ Chloroform } & $12.5 \mathrm{mg} / \mathrm{ml}$ & $1.000 \pm 0.4$ & $1.000 \pm 0.9$ & $1.667 \pm 0.6$ & $1.667 \pm 0.2$ \\
\hline & $25 \mathrm{mg} / \mathrm{ml}$ & $3.667 \pm 1.2$ & $6.000 \pm 0.8$ & $10.000 \pm 1.5$ & $9.667 \pm 1.2$ \\
\hline & $50 \mathrm{mg} / \mathrm{ml}$ & $21.000 \pm 0.9$ & $16.667 \pm 1.5$ & $17.667 \pm 1.6$ & $18.33 \overline{3} \pm 2$ \\
\hline \multirow[t]{3}{*}{ Ethyl acetate } & $12.5 \mathrm{mg} / \mathrm{ml}$ & $3.000 \pm 0.2$ & $2.000 \pm 0.4$ & $3.000 \pm 0.5$ & $1.667 \pm 0.2$ \\
\hline & $25 \mathrm{mg} / \mathrm{ml}$ & $7.000 \pm 1.7$ & $7.000 \pm 1.6$ & $8.667 \pm 1.9$ & $9.667 \pm 1.6$ \\
\hline & $50 \mathrm{mg} / \mathrm{ml}$ & $16.333+1.7$ & $18.000 \pm 1.6$ & $15.000 \pm 1.5$ & $18.00 \overline{0}+1$ \\
\hline \multirow[t]{3}{*}{ Aqueous } & $12.5 \mathrm{mg} / \mathrm{ml}$ & $1.333 \pm 0.5$ & $1.000 \pm 0.4$ & $1.667 \pm 0.2$ & $1.667+\underline{0 .} .2$ \\
\hline & $25 \mathrm{mg} / \mathrm{ml}$ & $7.33 \overline{3} \pm$ & $12.3 \overline{3} 3 \pm$ & $11.6 \overline{6} 7 \pm$ & $5.00 \overline{0}$ \\
\hline & $50 \mathrm{mg} / \mathrm{ml}$ & $15.667 \pm$ & $15.000+$ & $15.667 \pm$ & $17.667 \pm$ \\
\hline DMSO & & 0.000 & 0.000 & 0.000 & 0.000 \\
\hline
\end{tabular}

Values are mean \pm SEM of three independent experiments. 
Table 4. Minimum inhibitory concentrations (MIC) of plant Carium carvi crude extract against skin pathogens.

\begin{tabular}{|c|c|c|}
\hline Extracts & Bacteria isolates & MIC (mg/ml) \\
\hline \multirow[t]{4}{*}{ Hexane } & Staphylococcu aureus & 25.25 \\
\hline & Streptococcus pyogenes & 50.25 \\
\hline & Staphylococcus epidermidis & 25.25 \\
\hline & Pseudomonas aerugenosa & 65.25 \\
\hline \multirow{4}{*}{ Chloroform } & Staphylococcu aureus & 27.25 \\
\hline & Streptococcus pyogenes & 40.00 \\
\hline & Staphylococcus epidermidis & 25.25 \\
\hline & Pseudomonas aerugenosa & 35.50 \\
\hline \multirow[t]{4}{*}{ Ethylacetate } & Staphylococcu aureus & 25.50 \\
\hline & Streptococcus pyogenes & 25.50 \\
\hline & Staphylococcus epidermidis & 50.25 \\
\hline & Pseudomonas aerugenosa & 75.50 \\
\hline \multirow[t]{4}{*}{ Aqueous } & Staphylococcu aureus & 110.50 \\
\hline & Streptococcus pyogenes & 56.50 \\
\hline & Staphylococcus epidermidis & 125.50 \\
\hline & Pseudomonas aerugenosa & 150.50 \\
\hline
\end{tabular}

Table 5. Phytochemical analysis of Carium carvi seeds and Curcuma longa.

\begin{tabular}{|c|c|c|c|c|c|c|c|c|c|}
\hline \multirow[t]{2}{*}{ Plants } & \multicolumn{9}{|c|}{ Phytochemical tests } \\
\hline & Alkaloid & Carbohydrate & Glycoside & Saponin & Phenol & Tannins & Flavinoid & Protein & Starch \\
\hline Carium carvi Seeds & ++ & +++ & - & - & ++ & ++ & - & - & ++ \\
\hline Curcuma longa & + & +++ & ++ & - & - & ++ & - & + & - \\
\hline
\end{tabular}

- sign shows not detected; + shows compound present in small amount; ++ shows compound present in

moderate amount; +++ shows compound present in higher amount.

Conclusion: The extracts of $C$. carvi seed and C. longa showed promising results against clinically isolated skin related Staphylococcus epidermidis, Staphylococcus aureus, Pseudomonas aerugenosa andStreptococcus pyogenes pathogens. Therefore, it can be concluded that its extracts/isolated compounds could be useful natural alternative against these pathogens.

Ethical consideration: The work has been approved by the KUST Ethical Committee wide approval No. KUST/ Ethical Committee /16-05.

\section{Declarations:}

Competing interests: The authors declare that they have no competing interests.

\section{REFERENCES}

Abhilash, P., P. Nisha, A. Prathapan, S. V. Nampoothiri, O. L. Cherian, T. Sunitha, and K. Raghu. (2011). Cardioprotective effects of aqueous extract of Oxalis corniculata in experimental myocardial infarction. Exp. Toxicol. Pathol. 63(6):535-540.

Ahmad, I., and F. Aqil. (2007). In vitro efficacy of bioactive extracts of 15 medicinal plants against ES $\beta$ L-producing multidrug-resistant enteric bacteria. Microbiol. Res. 162(3):264-275.

Amin, G. (1991). Popular medicinal plants of Iran. Ministry of health:40-47.
Arayne, M. S., N. Sultana, and S. S. Bahadur. (2007). The berberis story: Berberis vulgaris in therapeutics. Pakistan J. Pharm.Sci. 20(1):83-92.

Babu, S., S. Satish, D. Mohana, M. Raghavendra, and K. Raveesha. (2007). Anti-bacterial evaluation and phytochemical analysis of some Iranian medicinal plants against plant pathogenic Xanthomonas pathovars. J. Agricultural Technology 3(2):307316.

Bashir, S., M. Alam, B. Ahmad, and A. Aman. (2014). Antibacterial, anti-fungal and phytotoxic activities of Ferula narthex Boiss. Pakistan J. Pharm. Sci 27(6):1819-1825.

Bladt, S. (2009). Plant Drug Analysis: A thin layer chromatography atlas. Springer Science \& Business Media.

Chevallier, A. (2001). Encyclopedia of Medicinal Plants Dorling Kindersley Limited. London.

Coyle, M. B. (2005). Manual of antimicrobial susceptibility testing. BCIT Imaging Services.

Farhoosh, R., G. A. Golmovahhed, and M. H. Khodaparast. (2007). Antioxidant activity of various extracts of old tea leaves and black tea wastes (Camellia sinensis L.). Food Chem. 100(1):231-236.

Fleming, S. W., L. H. Brown, and S. E. Tice. (2006). Community-acquired methicillin-resistant Staphylococcus aureus skin infections: Report of a local outbreak and implications for emergency 
department care. J. Am. Acad. Nurse Pract. 18(6):297-300.

Iyer, S., and D. H. Jones. (2004). Community-acquired methicillin-resistant Staphylococcus aureus skin infection: a retrospective analysis of clinical presentation and treatment of a local outbreak. JThe American Academy of Dermatology 50(6):854-858.

Jain, A., P. Tiwari, and M. Bashir. (2010). Nutritive aspects of Oxalis corniculata L. used by tribals of Central India during scarcity of food. Botany Research International 3:35-37.

Khan, H., M. A. Khan, and Abdullah. (2015). Antibacterial, antioxidant and cytotoxic studies of total saponin, alkaloid and sterols contents of decoction of Joshanda: Identification of components through thin layer chromatography. Toxicol. Ind. Health 31(3):202-208.

Khan, H., M. Saeed, N. Muhammad, and S. Perviz. (2016). Phytochemical analysis, antibacterial, and antifungal assessment of aerial parts of Polygonatum verticillatum. Toxicol. Ind. Health 32(5):841-847.

A. Nafissi (1990), “Foods and Drinks' Properties”Isfehan University Press, Isfehan, pp:150.

Končić, M. Z., D. Kremer, K. Karlović, and I. Kosalec. (2010). Evaluation of antioxidant activities and phenolic content of Berberis vulgaris L. and Berberis croatica Horvat. Food Chem. Toxicol. 48(8-9):2176-2180.

Kong, W.-J., H. Zhang, D.-Q. Song, R. Xue, W. Zhao, J. Wei, Y.-M. Wang, N. Shan, Z.-X. Zhou, and P. Yang. (2009). Berberine reduces insulin resistance through protein kinase $\mathrm{C}$-dependent up-regulation of insulin receptor expression. Metabolism 58(1):109-119.

Kumar, K. A., K. Das, M. Joshipura, and N. Mandal. (2010). Oxalis corniculata Linn.-The Plant of Indian subtropics-A Review. Herbal Tech Industry 8(2010):7-11.

Loke, M. F., and A. Hanafi. (2019). Molecular Mechanisms Responsible for Drug Resistance. Elsevier.

Paterson, D. L. (2006). The epidemiological profile of infections with multidrug-resistant Pseudomonas aeruginosa and Acinetobacter species. Clinical infectious diseases 43(Supplement_2):S43-S48.

Quave, C. L., M. Pardo-de-Santayana, and A. Pieroni. (2012). Medical ethnobotany in Europe: from field ethnography to a more culturally sensitive evidence-based cam? Evidence-based complementary and alternative medicine 2012

Raghavendra, M., S. Satish, and K. Raveesha. (2006). Phytochemical analysis and antibacterial activity of Oxalis corniculata; a known medicinal plant. My Sci 1(1):72-78.
Razzaghi-Abyaneh, M., M. Shams-Ghahfarokhi, M.-B. Rezaee, K. Jaimand, S. Alinezhad, R. Saberi, and T. Yoshinari. (2009). Chemical composition and antiaflatoxigenic activity of Carum carvi L., Thymus vulgaris and Citrus aurantifolia essential oils. Food Control 20(11):1018-1024.

Satish, S., M. Raghavendra, and K. Raveesha. (2008). Evaluation of the antibacterial potential of some plants against human pathogenic bacteria. Adv. Biol. Res. (Rennes) 2(3-4):44-48.

Shamsa, F., A. Ahmadiani, and R. Khosrokhavar. (1999). Antihistaminic and anticholinergic activity of barberry fruit (Berberis vulgaris) in the guineapig ileum. J. Ethnopharmacol. 64(2):161-166.

Sibi, G., V. Apsara, K. Dhananjaya, K. Ravikumar, and H. Mallesha. (2013). Phytochemical and antibacterial properties of spices against food borne bacteria with special reference to Parmelia perlata. Global J. Biosci. Biotechnol 2(2):145149.

Sivarajan, V., and I. Balachandran. (1994). Ayurvedic drugs and their plant sources. Oxford and IBH publishing.

Stevens, D. L., A. L. Bisno, H. F. Chambers, E. P. Dellinger, E. J. Goldstein, S. L. Gorbach, J. V. Hirschmann, S. L. Kaplan, J. G. Montoya, and J. C. Wade. (2014). Practice guidelines for the diagnosis and management of skin and soft tissue infections: 2014 update by the Infectious Diseases Society of America. Clinical infectious diseases 59(2):e10-e52.

Thippeswamy, N., K. A. Naidu, and R. N. Achur. (2013). Antioxidant and antibacterial properties of phenolic extract from Carum carvi L. J. Pharm. Res. 7(4):352-357.

Turkmen, N., F. Sari, and Y. S. Velioglu. (2006). Effects of extraction solvents on concentration and antioxidant activity of black and black mate tea polyphenols determined by ferrous tartrate and Folin-Ciocalteu methods. Food Chem. 99(4):835841.

Ullah, Z., A. Rehman, N. Ullah, S. Ahmad Khan, S. Khan, and I. Ahmad. (2013). Antibacterial study of Phyla nodiflora Linn. J. Chemical and Pharmaceutical Research 53:86-90.

Vuong, C., and M. Otto. (2002). Staphylococcus epidermidis infections. Microbes and infection 4(4):481-489.

Zhou, J., S. Zhou, J. Tang, K. Zhang, L. Guang, Y. Huang, Y. Xu, Y. Ying, L. Zhang, and D. Li. (2009). Protective effect of berberine on beta cells in streptozotocin-and high-carbohydrate/high-fat diet-induced diabetic rats. Eur. J. Pharmacol. 606(1-3):262-268. 